\title{
PENGEMBANGAN APLIKASI ANDROID PADA SISTEM PENDETEKSI DINI KEBAKARAN LAHAN
}

\author{
Nada Araminta ${ }^{1}$ \\ Program Studi Broadband Multimedia, Jurusan Teknik Elektro, Politeknik Negeri Jakarta \\ Email: nadaaraminta03@gmail.com \\ Agus Wagyana ${ }^{1}$ \\ Program Studi Broadband Multimedia, Jurusan Teknik Elektro, Politeknik Negeri Jakarta \\ Email: agus.wagyana@elektro.pnj.ac.id
}

\begin{abstract}
Land fires are a tragedy that is difficult to control if the fire is large and can result in considerable losses. To be able to reduce the impact of losses due to land fires, an early warning is needed, therefore an application system is made that can detect land fires based on fire, smoke and temperature parameters. The methods used in the process of making this application are application system planning, application feature planning, layout design and java programming for each feature using Android Studio, configuration and programming on firebase, and finally the application can be released. This application uses firebase as a database platform that will store sensor data, user data, and cloud functions. The way this application works is that the application will display data on land conditions in real time, and when there is a change in status, the firebase will execute a command to provide a fire status warning via push notification in the form of a "safe", "alert", "fire level 1" status, or "fire level 2" to the application so that landowners can act on them immediately. The quality of this application is assessed through testing based on the ISO/EIC 25010 standard, namely testing database accuracy, compatibility, usability, and performance efficiency aspects. With the test results of $100 \%$ database accuracy, $100 \%$ compatibility, and $86 \%$ usability, the application is categorized as very feasible and with $3,213 \%$ CPU usage efficiency and 159,213 KB memory that meets little eye standards, it shows that the "Siaga Api" application has very goodquality.

Keyword: Land Fire, Android Application, ISO/EIC 25010, Realtime Database, Monitoring Application.
\end{abstract}

\begin{abstract}
ABSTRAK: Kebakaran lahan merupakan tragedi yang sulit untuk dikendalikan jika api sudah besar dan dapat mengakibatkan kerugian yang cukup besar. Untuk dapat mengurangi dampak kerugian akibat kebakaran lahan, diperlukan adanya sebuah peringatan dini, maka dari itu dibuatlah sebuah sistem aplikasi yang dapat mendeteksi kebakaran lahan berdasarkan parameter api, asap dan suhu. Metode yang digunakan pada proses pembuatan aplikasi ini adalah perencanaan sistem aplikasi, perencanaan fitur aplikasi, perancangan layout serta pemrograman java untuk setiap fitur menggunakan Android Studio, konfigurasi dan pemrograman pada firebase, dan akhirnya aplikasi dapat di release. Aplikasi ini menggunakan firebase sebagai platform database yang akan menyimpan data sensor, data pengguna, serta cloud function. Cara kerja dari aplikasi ini adalah aplikasi akan menampilkan data kondisi lahan secara realtime, dan ketika terjadi perubahan status maka firebase akan mengeksekusi perintah untuk memberikan peringatan status kebakaran melalui push notification berupa status "aman", "waspada", "kebakaran level 1", atau "kebakaran level 2" ke aplikasi sehingga pemilik lahan dapat langsung bertindak menanganinya. Kualitas aplikasi ini dinilai melalui pengujian yang berdasarkan standar ISO/EIC 25010 yaitu pengujian akurasi database, aspek compatibility, usability, dan performance efficiency. Dengan hasil uji akurasi database $100 \%$, compatibility $100 \%$, dan usability $86 \%$ aplikasi dikategorikan sangat layak serta dengan performance efficiency CPU usage 3,213\% dan memory 159,213 KB yang memenuhi standar little eye menunjukkan bahwa aplikasi "Siaga Api" memiliki kualitas yang sangat baik.
\end{abstract}

Kata Kunci: Kebakaran Lahan, Aplikasi Android, ISO/EIC 25010, Realtime Database, Aplikasi Pemantauan.

\section{PENDAHULUAN}

Sekitar 98\% kebakaran hutan dan lahan gambut di Indonesia terjadi akibat ulah manusia, baik karena

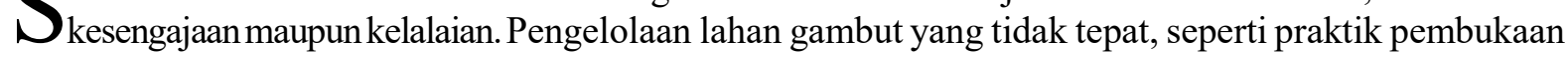
lahan untuk pertanian dan perkebunan, adalah beberapa contohnya. Pembukaan lahan ini biasanya diikuti pengeringan serta pembersihan lahan dengan api. Padahal, tanah gambut yang kering akan mudah sekali untuk terbakar jika terkena api.

Pada tahun 2019 lalu, kebakaran hutan dan lahan di Indonesia setidaknya menghanguskan 1,6 juta hektar lahan [1], dan sekitar 500 ribu hektarnya terjadi di lahan gambut. Sepanjang Januari hingga Desember 2019, terdapat 55.006 peringatan kebakaran di tujuh provinsi prioritas restorasi gambut, yaitu Jambi, Kalimantan Barat, Kalimantan Selatan, Kalimantan Tengah, Papua, Riau, dan Sumatera Selatan. Puncak peringatan kebakaran terjadi di bulan September [2].

Kebakaran lahan merupakan salah satu tragedi yang datangnya tidak dapat diprediksi, disamping tidak diinginkan oleh masyarakat juga sering tidak terkendalikan apabila api sudah besar. Kejadian kebakaran sangat membahayakan dan mengganggu kehidupan dan penghidupan masyarakat. Kebakaran dikategorikan sebagai salah satu bentuk bencana. Bencana adalah peristiwa atau rangkaian

\footnotetext{
${ }^{1}$ Program Studi Broadband Multimedia, Jurusan Teknik Elektro, Politeknik Negeri Jakarta
} 
peristiwa yang mengancam dan mengganggu kehidupan dan penghidupan masyarakat yang disebabkan oleh faktor alam dan/atau faktor non alam maupun faktor manusia sehingga mengakibatkan timbulnya korban jiwa, kerusakan lingkungan, kerugian harta benda dan dampak psikologis [3].

Dalam penanggulangan masalah kebakaran, banyak sekali ditemukan kesulitan-kesulitan, seperti sukarnya ditemukan sumber api yang menyala, sehingga api akan terus menjalar ke tempat lain dan kerugian pun akan menjadi semakin besar. Untuk itu perlu adanya sebuah sistem yang memudahkan untuk memperoleh peringatan informasi potensi kebakaran di suatu lahan. Informasi potensi kebakaran tersebut dapat diketahui salah satunya dari asap seperti dalam penelitian Dani Sasmoko dan Arie Mahendra (2017) yang membuat sistem pendeteksi kebakaran berbasis IoT dan SMS gateway menggunakan arduino dengan tujuan untuk mengurangi resiko dan tingkat penyakit yang disebabkan oleh asap kebakaran hutan [4].

Informasi potensi kebakaran tersebut harus dapat dikirimkan secara realtime kepada pemilik lahan. Siswanto et al (2020) dalam penelitiannya membuat sebuah prototype Wireless Sensor Network (WSN) sistem pendeteksi dini kebakaran yang dapat mengirimkan informasi dari sensor ke penjaga hutan melalui internet [5]. Joniwarta et al (2019) dalam penelitiannya mengenai sistem monitoring kebakaran berbasis SMS gateway, menggunakan SMS dan alarm untuk dapat memberikan peringatan secara otomatis ke user ketika terjadi kebakaran [6].

Penelitian ini mengembangan dari penelitian-penelitian sebelumnya yang telah disebutkan diatas, yakni sistem peringatan dini kebakaran yang akan menggunakan sensor api flame detectors, sensor asap MQ-7, dan sensor suhu LM35 untuk dapat memprediksi potensi kebakaran menggunakan Arduino Nano yang nantinya data akan diterima oleh NodeMCU ESP32 melalui LoRa RA-02 SX1278. Informasi yang diperoleh dari sensor tersebut dikirimkan secara realtime ke cloud dan akan memberikan peringatan langsung secara personal kepada pemilik lahan melalui push notification sebuah aplikasi yang didesain khusus.

\section{METODOLOGI}

Pengembangan aplikasi android pada sistem pendeteksi dini kebakaran lahan bekerja berdasarkan hardware dari sistem pendeteksi dini kebakaran lahan yang diinstalasi pada sebuah maket lahan. Diagram blok dari sistem pendeteksi dini kebakaran lahan yang terintegrasi dengan aplikasi android ditunjukkan pada Gambar 1.

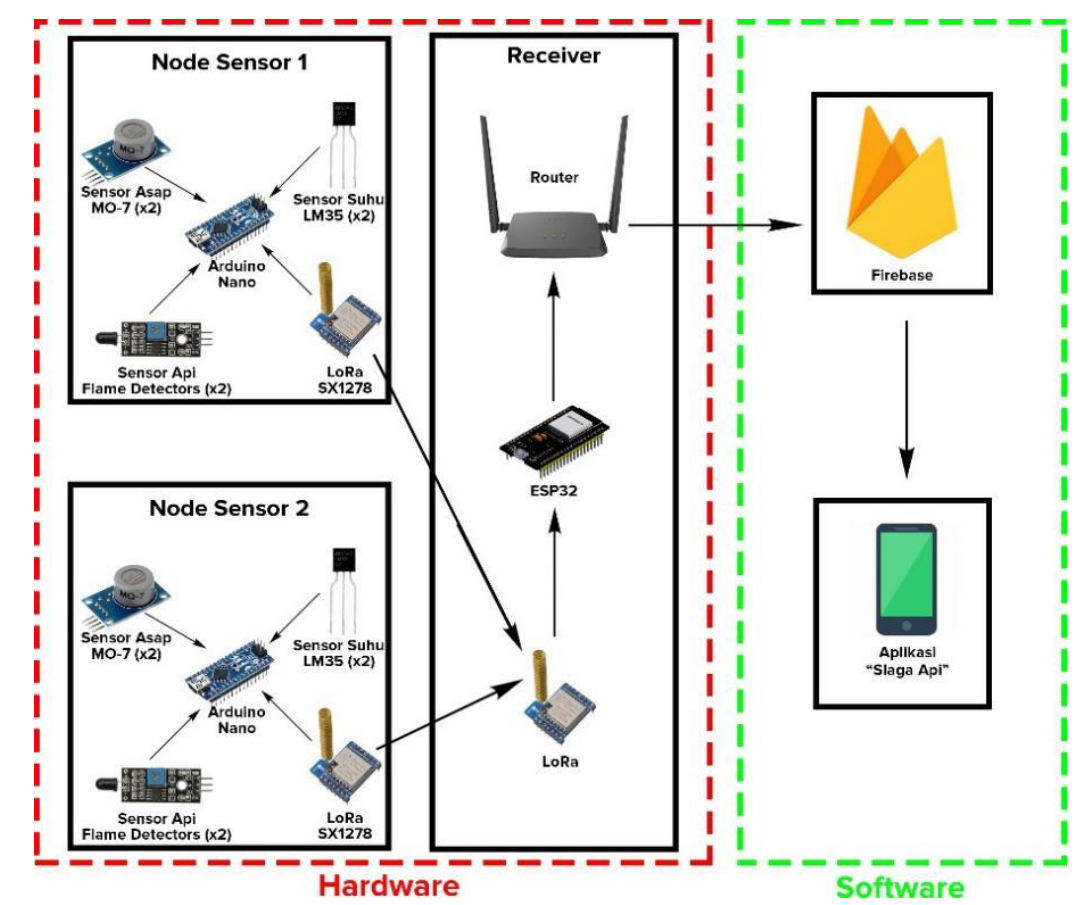

Gambar 1. Diagram Blok Sistem Pendeteksi Dini Kebakaran Lahan yang Terintegrasi dengan Aplikasi Android 
Diagram blok diatas menggambarkan alur kerja dari sistem ini. Dimulai dari pembacaan terdeteksinya api atau tidak oleh sensor api flame detectors, pembacaan terdeteksinya asap atau tidak sensor tersebut dikirimkan ke database realtime Firebase dengan koneksi router WiFi. Data yang telah disimpan oleh database kemudian diambil oleh aplikasi "Siaga Api" untuk ditampilkan sebagai sistem monitoring, dan ketika ada perubahan data status pada database maka Firebase akan mengirimkan push notification ke aplikasi "Siaga Api" mengenai status potensi kebakaran.

Selain diagram blok, terdapat skematik juga yang digunakan untuk mempermudah proses perangkaian komponen dan perangkat serta mempermudah untuk pengalokasian pin. Pada sistem ini skematik terbagi menjadi dua bagian, yaitu pada sisi transmitter dan pada sisi receiver. Skematik rangkaian diperlihatkan pada Gambar 2 dan Gambar 3.

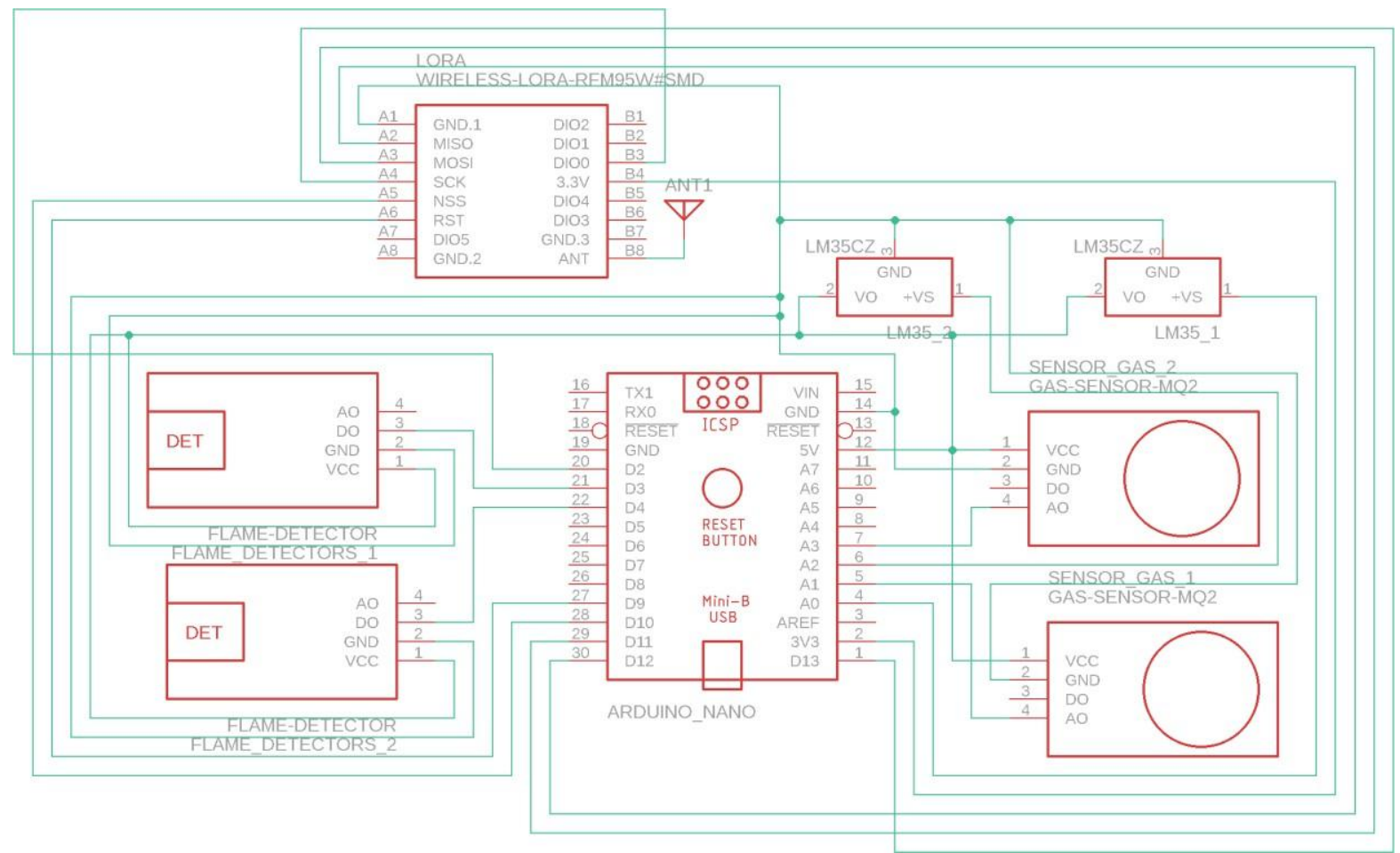

Gambar 2. Skematik Rangkaian pada Sisi Transmitter

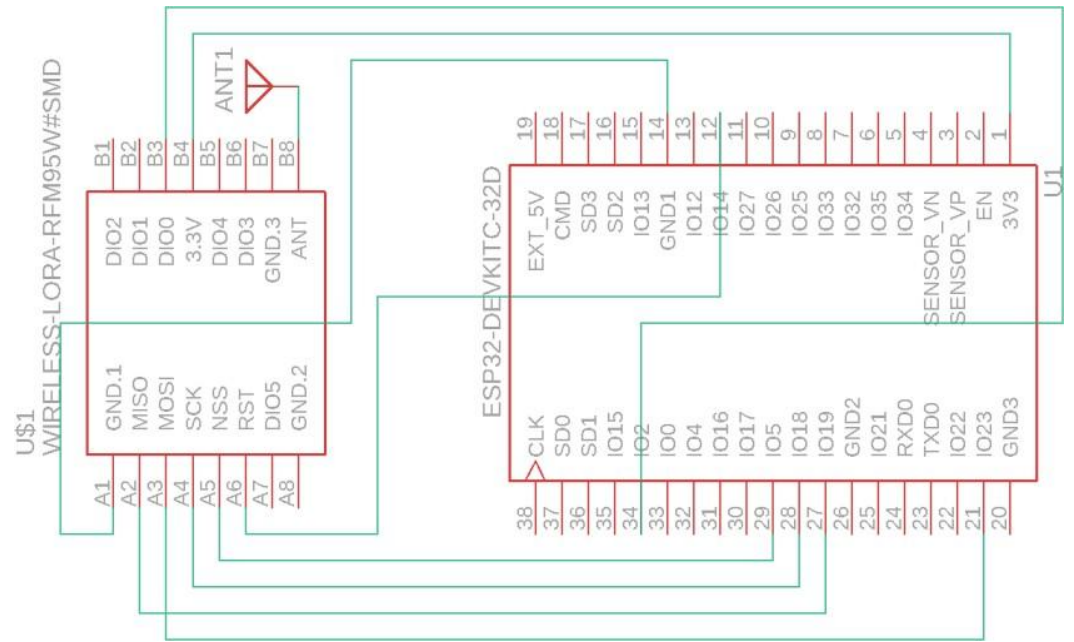

Gambar 3. Skematik Rangkaian pada Sisi Receiver

Pengembangan aplikasi android pada sistem pendeteksi dini kebakaran lahan ini juga memiliki tiga bagian cara kerja, yaitu cara kerja hardware, pembuatan aplikasi, dan cara kerja aplikasi. Flowchart dari cara kerja hardware, pembuatan aplikasi, dan cara kerja aplikasi ditunjukkan pada Gambar 4, Gambar 5, dan Gambar 6. 


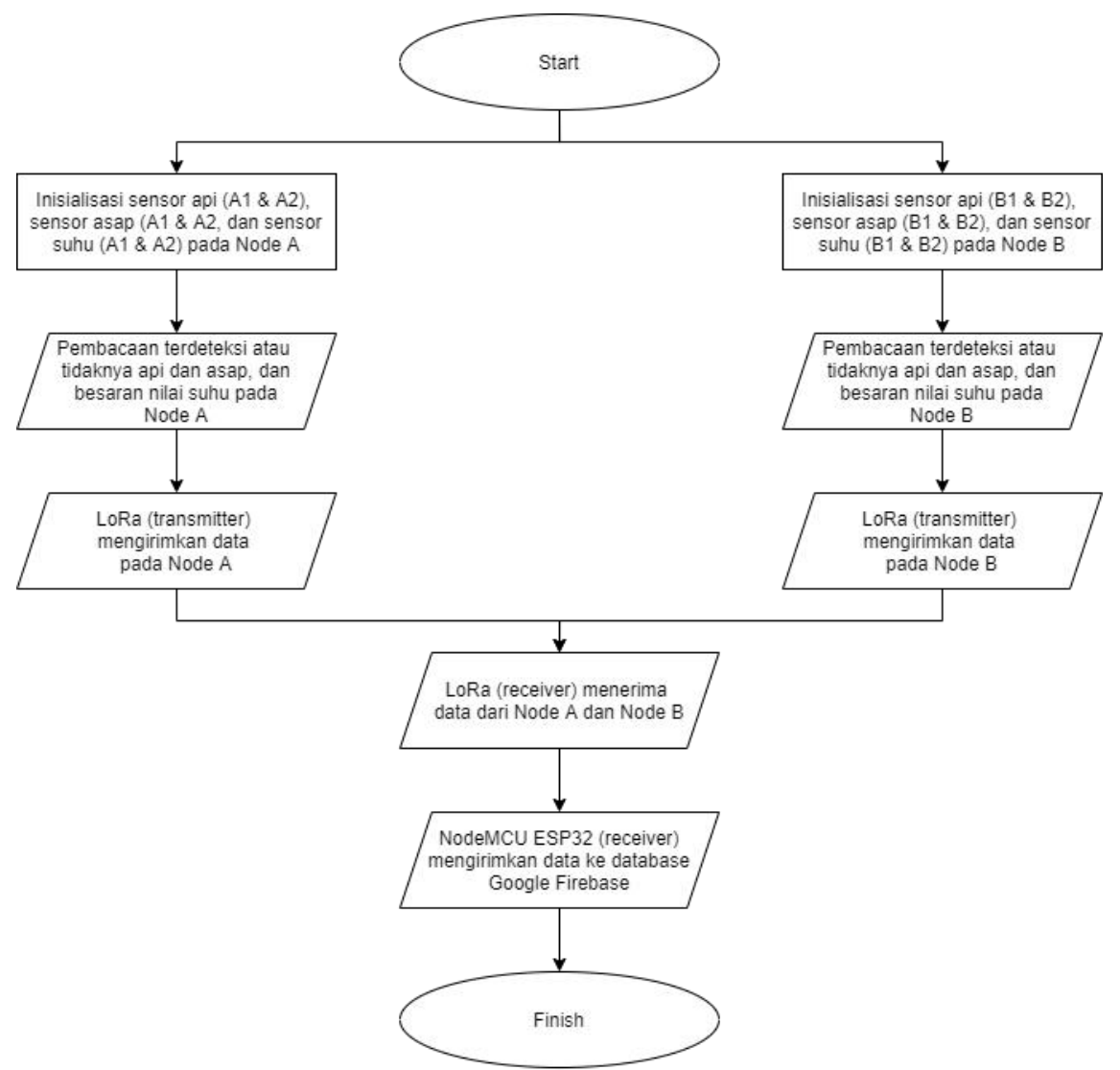

Gambar 4. Flowchart Cara Kerja Hardware

Berdasarkan flowchart pada Gambar 4, dapat diketahui proses pembuatan aplikasi dari sistem sebagai berikut :

1. Pada sistem pendeteksi dini kebakaran lahan, terbagi menjadi Node A dan Node B yang masing masing dari node tersebut memiliki komponen 1 buah Arduino Nano, 1 buah LoRa RA-02 SX1278, 2 buah sensor api flame detectors, 2 buah sensor asap MQ-7, dan sensor suhu LM35. Tahap awal dari alur kerja sistem ini adalah proses inisialisasi pin dari setiap komponen yang digunakan pada Arduino Nano. Sensor api flame detectors memerlukan 2 buah pin digital, sensor asap MQ-7 memerlukan 2 buah pin analog, sensor suhu LM35 memerlukan 2 buah pin analog, dan LoRa RA-02 SX1278 memerlukan 6 pin digital. Sehingga terdapat total 8 pin digital dan 4 pin analog. Terdapat juga pin $3.3 \mathrm{~V}$ sebanyak 1 buah, pin VCC sebanyak 6 buah, dan pin GND sebanyak 7 buah.

2. Setelah tiap pin yang digunakan di inisialisasi oleh Arduino Nano, selanjutnya sensor api flame detectors, sensor asap MQ-7, dan sensor suhu LM35 akan bekerja. Sensor api flame detectors akan mendeteksi ada atau tidak adanya api, sensor asap MQ-7 akan mendeteksi besaran nilai asap pada lahan, dan sensor suhu LM35 akan mendeteksi besaran nilai suhu pada lahan.

3. Setelah data dari sensor didapatkan, LoRa RA-02 SX1278 pada masing-masing node akan mengirimkan data kepada LoRa RA-02 SX1278 yang terdapat pada sisi receiver.

4. Selanjutnya NodeMCU ESP32 akan mengirimkan data ke Google Firebase untuk dikirimkan langsung ke aplikasi yang digunakan sebagai monitoring lahan. 


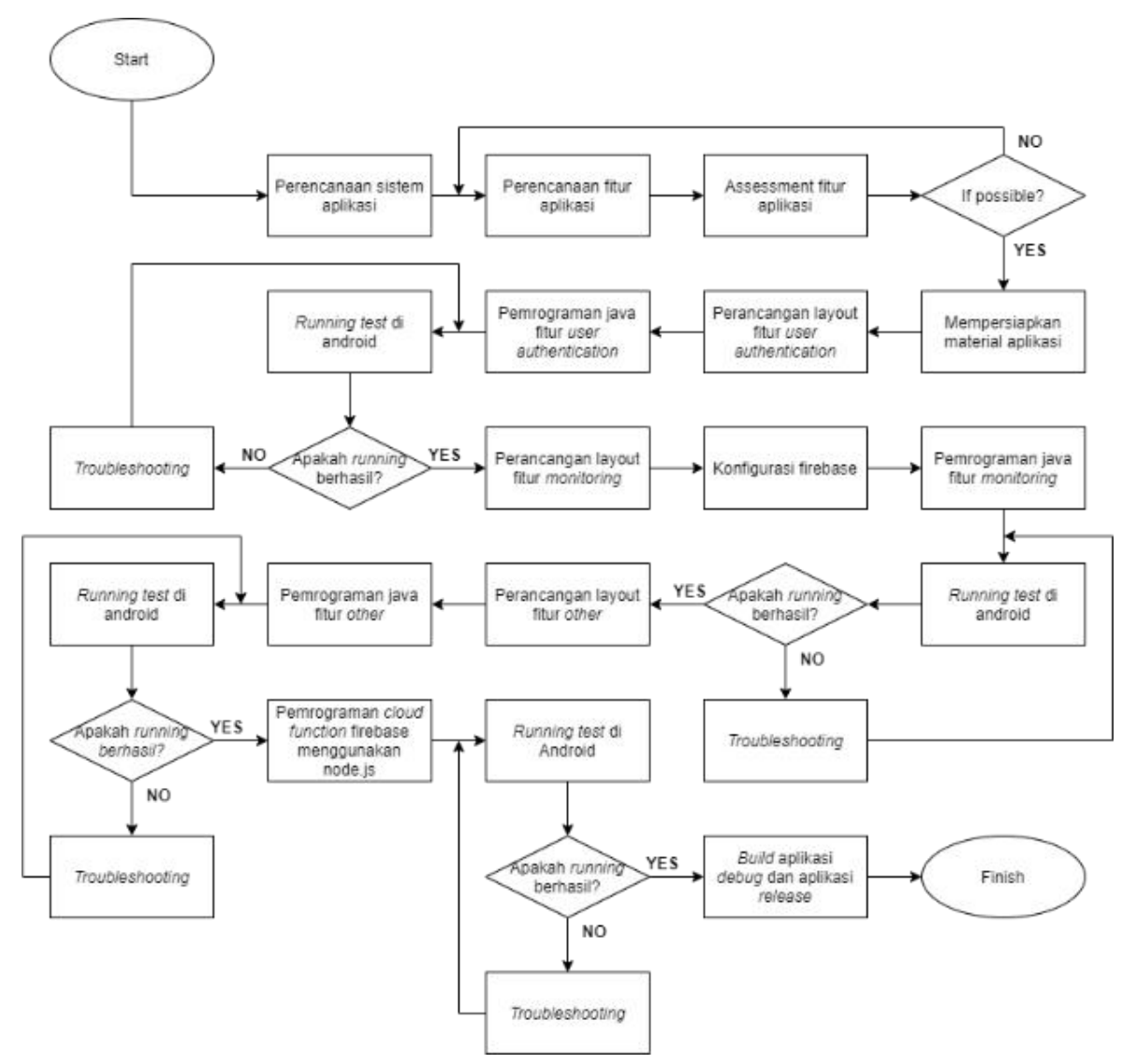

- Gambar 5. Flowchart Pembuatan Aplikasi

Berdasarkan flowchart pada Gambar 5, dapat diketahui proses pembuatan aplikasi dari sistem sebagai berikut :

1. Langkah pertama yang harus dilakukan dalam proses pembuatan aplikasi ada merencanakan sistem aplikasi seperti apa yang ingin dibuat. Pada aplikasi ini sistem aplikasi yang akan dibuat aplikasi ini dapat digunakan pada sistem operasi Android 5.0 (Lollipop) sampai dengan Android 11.0 (R) dan dapat digunakan pada API level 21 sampai dengan 30. Sistem aplikasi ini juga bekerja dengan cara menampilkan hasil monitoring dari data yang didapatkan dari sensor dan memberikan notifikasi peringatan juga ada perubahan status.

2. Jika sudah menentukan sistem aplikasi, maka langkah selanjutnya adalah perencanaan fitur aplikasi. Pada aplikasi ini, fitur yang digunakan dibagi menjadi 3, yaitu fitur user authentication, fitur monitoring, dan fitur other. Lalu dilakukan assessment fitur untuk mengetahui apakah fitur- fitur yang ada bisa dibuat di Android Studio atau tidak? Jika tidak, maka fitur yang ada harus disesuaikan kembali. Jika iya, maka bisa dilanjutkan dengan menentukan material yang akan digunakan untuk proses pembuatan aplikasi. Pada aplikasi ini, fitur-fitur yang direncanakan bisa dibuat menggunakan Android Studio, maka dapat berlanjut ke proses mempersiapkan material aplikasi.

3. Karena fitur-fitur yang direncanakan bisa dibuat menggunakan Android Studio, maka langkah selanjutnya adalah mempersiapkan segala material yang dibutuhkan. Adapun material yang dibutuhkan, yaitu logo aplikasi, icon/symbol yang digunakan untuk aplikasi, kode warna yang digunakan untuk aplikasi, dan lain-lain.

4. Fitur pertama yang dibuat adalah fitur user authentication. Didalam fitur user authentication terdapat beberapa tampilan halaman aplikasi dan pemrograman javanya, yaitu halaman login, halaman registrasi, halaman lupa password, dan halaman verifikasi. Tahap awal yang harus dilakukan adalah merancang layout untuk masing-masing halaman, selanjutnya melakukan pemrograman java 
5. untuk masing-masing halaman, lalu lakukan running test di handphone Android. Jika gagal, lakukan troubleshooting agar aplikasi bisa di run kembali. Jika berhasil, maka lanjut mengerjakan fitur berikutnya.

6. Fitur kedua yang dibuat adalah fitur monitoring. Didalam fitur monitoring terdapat beberapa tampilan halaman aplikasi dan pemrograman javanya, yaitu halaman "status", halaman "api", halaman "asap", dan halaman "suhu". Tahap awal yang harus dilakukan adalah merancang layout untuk masing-masing halaman, selanjutnya melakukan pemrograman java untuk masing- masing halaman, lalu lakukan running test di handphone Android. Jika gagal, lakukan troubleshooting agar aplikasi bisa di run kembali. Jika berhasil, maka lanjut mengerjakan fitur berikutnya.

7. Fitur ketiga yang dibuat adalah fitur other. Didalam fitur other terdapat beberapa tampilan halaman aplikasi dan pemrograman javanya, yaitu halaman "tentang", halaman "tentang aplikasi", dan halaman "tentang kami", dan halaman verifikasi. Tahap awal yang harus dilakukan adalah merancang layout untuk masing-masing halaman, selanjutnya melakukan pemrograman java untuk masing-masing halaman, lalu lakukan running test di handphone Android. Jika gagal, lakukan troubleshooting agar aplikasi bisa di run kembali. Jika berhasil, maka lanjut mengerjakan langkah berikutnya.

8. Langkah selanjutnya adalah melakukan pemrograman cloud function firebase menggunakan node.js. Pemrograman ini berfungsi untuk mentrigger push notification jika ada perubahan status pada database firebase. Apabila sudah dilakukan pemrograman, selanjutnya adalah running test di handphone Android. Jika gagal, lakukan troubleshooting agar aplikasi bisa di run kembali. Jika berhasil, maka lanjut mengerjakan langkah berikutnya.

9. Jika running test dari pemrograman cloud function firebase sudah berhasil dan tidak ada kendala lagi, maka aplikasi dapat di release dan digunakan oleh user.

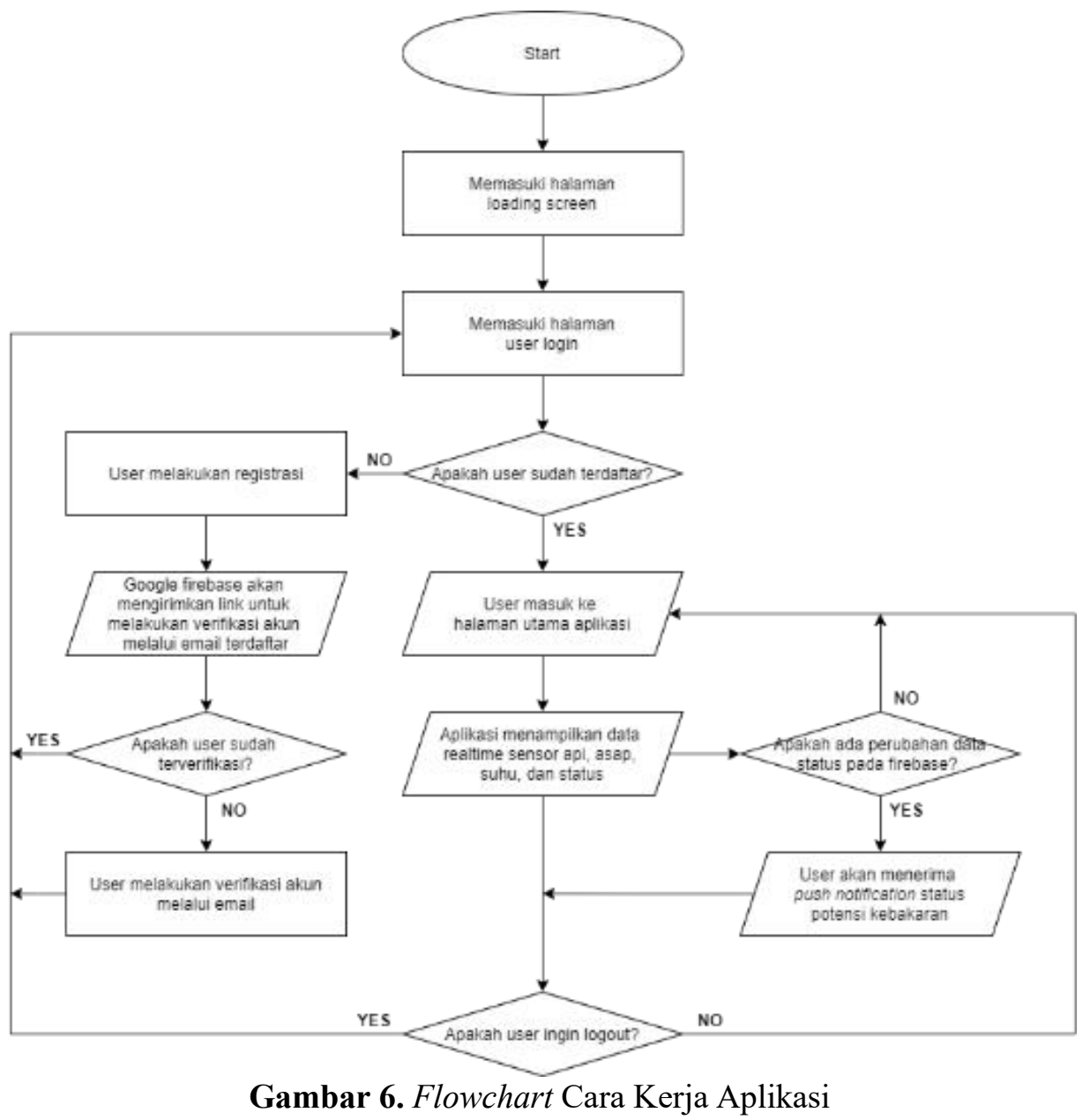


Berdasarkan flowchart pada Gambar 6, dapat diketahui bahwa aplikasi sistem pendeteksi dini kebakaran lahan berbasis Android memiliki alur kerja sebagai berikut :

1. Ketika memasuki aplikasi, halaman awal yang akan muncul adalah halaman loading screen. Halaman loading screen merupakan layar pembuka setiap kali pengguna menjalankan aplikasi.

2. Untuk dapat mengakses aplikasi, pengguna harus melakukan login akun terlebih dahulu, jika pengguna belum memiliki akun maka pengguna harus mendaftar atau melakukan registrasi terlebih dahulu. Pembuatan akun dilakukan dengan mendaftarkan nama pengguna, alamat email, password, dan konfirmasi password.

3. Setelah pengguna memiliki akun, pengguna harus melakukan verifikasi akun melalui link yang dikirim oleh Google Firebase melalui email yang didaftarkan. Jika pengguna sudah melakukan verifikasi akun maka pengguna bisa melakukan aktivitas login. Namun jika pengguna belum melakukan verifikasi akun maka pengguna tidak bisa melakukan aktivitas login.

4. Jika akun sudah terverifikasi, maka pengguna dapat melakukan aktivitas login dan pengguna dapat mengakses halaman utama dari aplikasi. Pada halaman utama ini pengguna dapat me- monitoring terdeteksi atau tidaknya api, besaran nilai asap, besaran nilai suhu, dan status pada maket.

5. Ketika ada perubahan data pada database status, pengguna akan menerima push notification meskipun aplikasi sedang tidak dijalankan atau dalam posisi background activity.

Spesifikasi aplikasi yang dirancang untuk sistem pendeteksi dini kebakaran lahan ditunjukkan pada Tabel 1 berikut ini.

Tabel 1. Spesifikasi Mobile Application Pada Sistem Pendeteksi Dini Kebakaran Nama Lahan Berbasis Android

\begin{tabular}{cc} 
Nama & Keterangan \\
\hline Sistem Operasi & Android 5.0 (Lollipop) - \\
& Android 11.0 (R) \\
API Level & $21-30$ \\
\hline
\end{tabular}

Aplikasi "Siaga Api" ini juga memiliki 4 perubahan status, yaitu :

1. Status "AMAN" yang ditandai dengan tidak ada api, tidak ada asap, dan suhu $<35^{\circ} \mathrm{C}$ pada masing-masing node dan masing-masing titik.

2. Status "WASPADA" yang ditandai dengan tidak ada api, ada asap, dan suhu $\geq 35^{\circ} \mathrm{C}$ pada salah satu titik yang sama di salah satu node, atau bahkan pada kedua titik di salah satu node.

3. Status "KEBAKARAN LEVEL 1" yang ditandai dengan ada api pada salah satu titik di salah satu node, ada asap, dan suhu $\geq 35^{\circ} \mathrm{C}$.

4. Status "KEBAKARAN LEVEL 2" yang ditandai dengan ada api pada kedua titik di salah satu node, ada asap, dan suhu $\geq 35^{\circ} \mathrm{C}$.

Realisasi mobile application pada sistem pendeteksi dini kebakaran lahan berbasis Android dapat dilihat pada Gambar 7 berikut ini. 

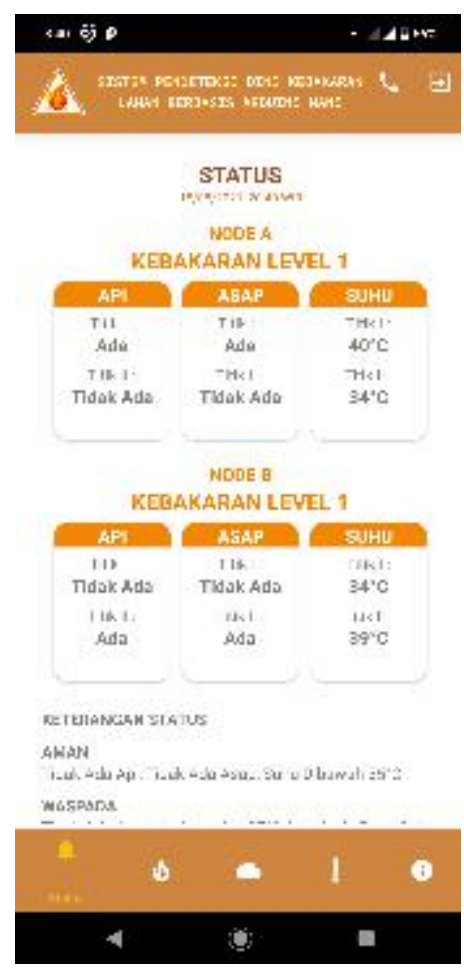

(a)

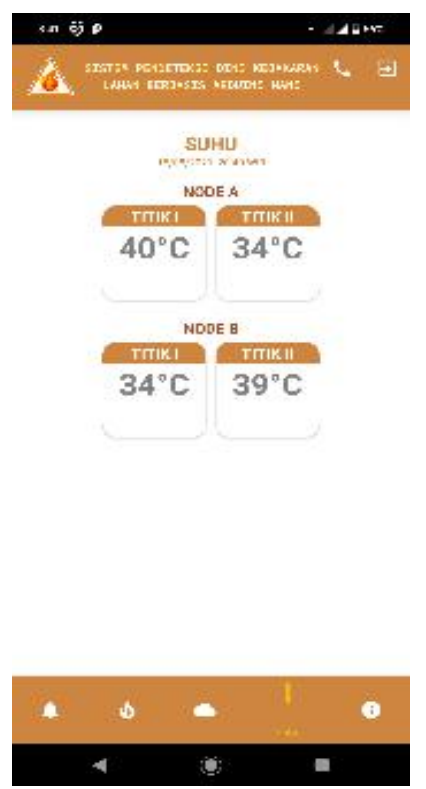

(d)
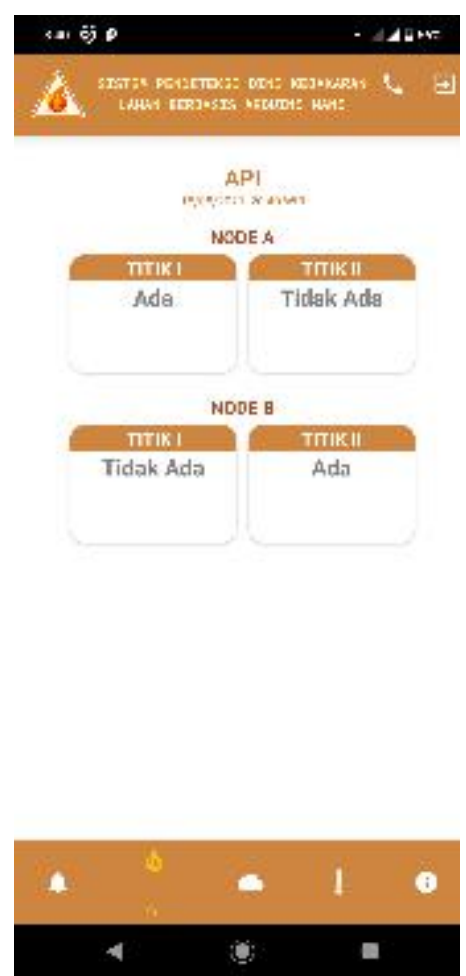

(b)

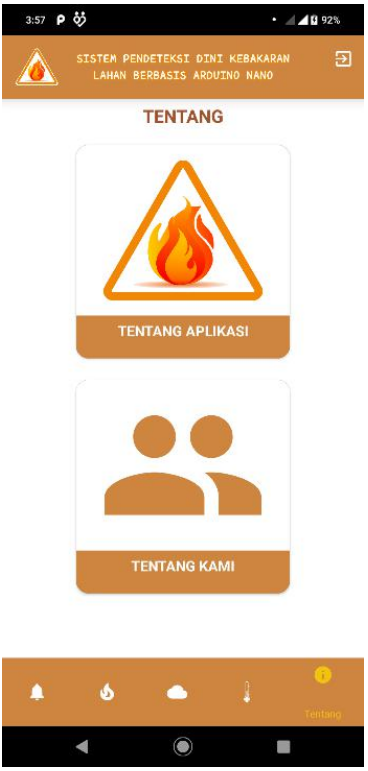

(e)
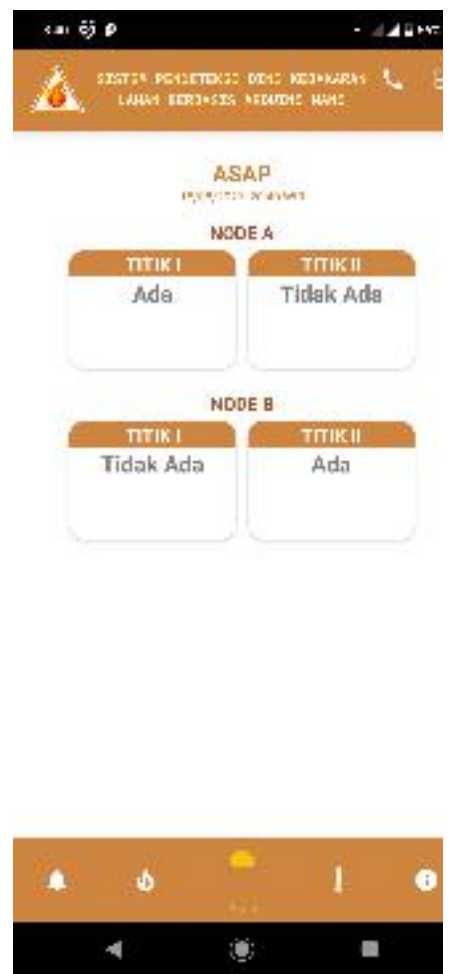

(c)

Gambar 7. Realisasi Mobile Application Pada Sistem Pendeteksi Dini Kebakaran Lahan Berbasis Android

(a) Tampilan Halaman "Status", (b) Tampilan Halaman "Api", (c) Tampilan Halaman "Asap", (d) Tampilan Halaman "Suhu", (d) Tampilan Halaman "Tentang"

Langkah-langkah pengujian yang dilakukan adalah sebagai berikut :

1. Pengujian akurasi database bertujuan untuk menguji ketepatan reading realtime database Firebase.

2. Pengujian kualitas aplikasi menggunakan standar ISO/EIC 25010 pada karakteristik aspek compatibility, aspek usability, dan aspek performance efficiency yang dijelaskan sebagai berikut:

a. Karakteristik aspek compatibility bertujuan untuk mengetahui kemampuan aplikasi untuk berjalan pada environment yang berbeda. Setelah dilakukan pengujian, selanjutnya dilakukan perhitungan persentase keberhasilan 
b. menggunakan rumus pada Persamaan (1) sebagai berikut :

Persentase keberhasilan $(\%)=$ Skor yang didapat $\times 100 \%$

1)

Setelah dilakukan perhitungan, nilai persentase yang didapatkan akan diklasifikasikan berdasarkan Tabel 2.

- Tabel 2. Standar Kelayakan Aplikasi

\begin{tabular}{cc}
\hline Persentase Skor & Interpretasi \\
\hline $81 \%-100 \%$ & Sangat layak \\
$61 \%-80 \%$ & Layak \\
$41 \%-60 \%$ & Cukup layak \\
$21 \%-40 \%$ & Tidak layak \\
$0 \%-20 \%$ & Sangat tidak layak \\
\hline
\end{tabular}

c. Karakteristik aspek usability bertujuan untuk mengetahui sistem aplikasi dapat bekerja dengan baik apabila dipergunakan oleh pengguna, sehingga semua kemampuan sistem dapat dapat bermanfaat secara maksimal. Pengujian ini dilakukan dengan menyebarkan kuesioner yang berisikan pertanyaan mengenai aplikasi berdasarkan ada metode System Usability Scale (SUS). Pada metode SUS terdapat nilai skala aspek usability. Nilai skala aspek usability ditunjukkan pada Tabel 3.

- Tabel 3. Nilai Skala Aspek Usability

\begin{tabular}{cccccc}
\hline PK & ST & TS & R & S & SS \\
\hline Nilai & 1 & 2 & 3 & 4 & 5 \\
\hline
\end{tabular}

Keterangan :

- PK: Pertanyaan Kuesioner

- ST: Sangat Tidak Setuju

- TS: Tidak Setuju

- $\quad$ R: Ragu-Ragu

- $\quad$ S: Setuju

- SS: Sangat Setuju

d. Karakteristik aspek performance efficiency bertujuan untuk mengetahui dan menguji kinerja aplikasi untuk sub-karakteristik resource utilization agar dapat memenuhi persyaratan ketika menjalankannya. Aspek performance efficiency dilakukan untuk mengetahui dan menguji kinerja aplikasi yaitu jumlah dan jenis sumber daya yang digunakan oleh sistem dengan menggunakan tools pengujian Firebase Test Lab dengan cara uji coba RoboTest. Pengujian yang dilakukan adalah melihat performansi pada CPU usage dan memory.

3. Pengujian sistem notifikasi peringatan bertujuan untuk mengetahui apakah sistem pemberian warning melalui push notification ke aplikasi dapat berjalan dengan baik, dan bagaimana performansinya. Response time pada database merupakan waktu yang dibutuhkan oleh client untuk mengirimkan request atau permintaan ke server database dan menerima respon dari server database. Request dapat berupa writing, reading, connecting, disconnecting, maupun broadcast. Writing merupakan sebuah request untuk melakukan penulisan data pada database. Reading merupakan request untuk membaca data yang ada pada database. Connect-disconnect merupakan request untuk berkomunikasi dengan data, dan broadcast merupakan request untuk mengirimkan informasi pembaruan data pada database ke semua client. Response time database dapat dikategorikan berdasarkan standar Query Response Time index (QRTi) MySQL Enterprise ditunjukkan pada Tabel 4. 
Tabel 4. Kategori Response Time Berdasarkan Standar QRTi MySQL Enterprise

\begin{tabular}{cc}
\multicolumn{2}{c}{ (Sumber: QRTi MySQL Enterprise) } \\
\hline $\begin{array}{c}\text { Kategori } \\
\text { Response Time }\end{array}$ & $\begin{array}{c}\text { Response Time } \\
(\mathbf{m s})\end{array}$ \\
\hline Optimum & 100 \\
Acceptable & $100-400$ \\
Unacceptable & $>400$ \\
\hline
\end{tabular}

PENGUJIAN PENELITIAN

Terdapat 5 pengujian yang dilakukan, yaitu pengujian akurasi database, pengujian compatibility aplikasi, pengujian usability aplikasi, pengujian performance efficiency aplikasi, dan pengujian sistem notifikasi peringatan.

a) Pengujian Akurasi Database

Pengujian akurasi database bertujuan untuk mengetahui ketepatan antara realtime database pada Firebase dengan aplikasi "Siaga Api" agar mengetahui apakah sistem aplikasi dapat bekerja dengan baik dan dapat memenuhi tujuan penelitian. Tingkat akurasi ini ditinjau dari masing-masing data sensor yang digunakan, yaitu data ada atau tidak adanya api, ada atau tidak adanya asap, dan besaran nilai suhu. Pengujian ini akan dilakukan pada realtime database Firebase dan tampilan pada aplikasi "Siaga Api".

\section{b) Pengujian Compatibility Aplikasi}

Pengujian compatibility aplikasi bertujuan untuk mengetahui kemampuan aplikasi untuk berjalan pada environment yang berbeda. Pengujian ini dilakukan dengan melakukan instalasi dan menjalankan aplikasi pada 5 perangkat handphone dengan spesifikasi yang berbeda. Pengujian compatibility aplikasi akan membuktikan apakah sistem aplikasi sudah mampu untuk diinstal dan dijalankan pada environment yang berbeda. Perangkat yang digunakan dalam proses pengujian compatibility aplikasi ini terdapat pada Tabel 5 .

Tabel 5. Perangkat Handphone yang Digunakan dalam Proses Pengujian Compatibility Aplikasi

\begin{tabular}{clc}
\hline No. & Perangkat & Spesifikasi \\
\hline 1 & Samsung Galaxy A32 & Versi Android : 11 \\
& & API Level : 33 \\
2 & Oppo A57 & Versi Android : 6 \\
& & API Level : 23 \\
3 & Xiaomi Redmi Note 10 & Versi Android : 11 \\
& & API Level : 30 \\
4 & Samsung Galaxy A20 & Versi Android : 10 \\
& & API Level : 29 \\
5 & Asus Zenfone 5 & Versi Android : 9 \\
& & API Level : 28 \\
\hline
\end{tabular}

c) Pengujian Usability Aplikasi

Pengujian usability aplikasi bertujuan untuk mengetahui sistem aplikasi dapat bekerja dengan baik apabila dipergunakan oleh pengguna, sehingga semua kemampuan sistem dapat bermanfaat secara maksimal. Pengujian ini dilakukan dengan menggunakan metode System Usability Scale (SUS). Pengujian ini akan dilakukan dengan cara menyebarkan kuesioner yang berisi pertanyaan mengenai aplikasi berdasarkan pada 
metode SUS. Platform yang digunakan untuk melakukan pengujian ini adalah google form dan menggunakan skala likert sebagai parameternya untuk mengukur penilaian dari reponden. Skala yang digunakan terdiri dari 1 sampai dengan 5. Pertanyaan yang digunakan pada kuesioner ini berdasarkan pada metode SUS sebagai berikut yang tertera pada Tabel 6 .

- Tabel 6. Pertanyaan Metode SUS

\begin{tabular}{cl}
\hline Kode & \multicolumn{1}{c}{ Pertanyaan } \\
\hline Q1 & Saya akan menggunakan aplikasi ini lagi. \\
Q2 & Saya merasa aplikasi ini rumit untuk digunakan. \\
Q3 & Saya merasa aplikasi ini mudah digunakan. \\
Q4 & Saya membutuhkan bantuan dari orang lain atau teknisi dalam menggunakan aplikasi ini. \\
Q5 & Saya merasa fitur-fitur aplikasi ini berjalan dengan semestinya. \\
Q6 & Saya merasa ada banyak hal yang tidak konsisten pada aplikasi ini. \\
Q7 & Saya merasa orang lain akan memahami cara menggunakan aplikasi ini dengan cepat. \\
Q8 & Saya merasa aplikasi ini membingungkan. \\
Q9 & Saya merasa tidak ada hambatan dalam menggunakan aplikasi ini. \\
Q10 & Saya perlu membiasakan diri terlebih dahulu sebelum menggunakan aplikasi ini. \\
\hline
\end{tabular}

\section{d) Pengujian Performance Efficiency Aplikasi}

Pengujian performance efficiency aplikasi bertujuan untuk mengetahui dan menguji kinerja aplikasi untuk sub-karakteristik resource utilization agar dapat memenuhi persyaratan ketika menjalankannya. Resource utilization adalah jumlah dan jenis sumber daya yang digunakan oleh sistem atau produk agar dapat memenuhi persyaratan ketika menjalankannya. Pengujian ini dilakukan dengan menggunakan fitur Firebase Test Lab, dengan uji coba RoboTest, untuk mengetahui penggunaan CPU usage, dan memory pada perangkat saat menjalankan aplikasi "Siaga Api" sehingga dapat diketahui performansinya. Pada Firebase Test Lab, simulation device yang digunakan adalah Pixel 3, API Level 28.

\section{e) Pengujian Sistem Notifikasi Peringatan}

Pengujian sistem notifikasi peringatan bertujuan untuk mengetahui apakah sistem pemberian warning melalui push notification ke aplikasi dapat berjalan dengan baik, dan bagaimana performansinya. Pengujian performansi dilakukan dengan Firebase function log melalui console Firebase. Pengujian ini juga bertujuan untuk mengukur waktu yang dibutuhkan untuk melakukan proses pengiriman warning kepada pengguna.

\section{HASIL PENELITIAN}

Dari 5 pengujian penelitian yang telah dijelaskan diatas, maka berikut ini merupakan hasil yang didapatkan dari pengujian penelitian tersebut.

\section{a. Hasil Pengujian Akurasi Database}

Pada hasil pengujian akurasi sensor akan dilihat bagaimana keakuratan dari masingmasing data pada database Firebase dengan data yang ditampilkan pada aplikasi "Siaga Api". Pengujian dilakukan pada sensor api flame detectors, sensor asap MQ-7, dan sensor suhu LM35. Hasil pengujian ini ditunjukkan pada Tabel 7, Tabel 8, dan Tabel 9.

Tabel 7. Hasil Pengujian Database Sensor Api Flame Detectors

\begin{tabular}{cccccc}
\hline No. & Data & $\begin{array}{c}\text { Data Realtime } \\
\text { Database }\end{array}$ & $\begin{array}{c}\text { Data } \\
\text { Aplikasi }\end{array}$ & Sesuai & $\begin{array}{c}\text { Tidak } \\
\text { Sesuai }\end{array}$ \\
\hline 1 & Api A1 & Ada & Ada & $\checkmark$ & \\
2 & Api A2 & Tidak Ada & Tidak Ada & $\checkmark$ &
\end{tabular}


Tidak Ada

Api B2

Ada

Tidak Ada

4

Berdasarkan data pada tabel diatas dapat diketahui bahwa semua data sensor api yang ditampilkan di aplikasi sesuai dengan data yang disimpan di realtime database sehingga dapat disimpulkan bahwa realtime database sensor api flame detectors memiliki accuration rate sebesar $100 \%$.

Tabel 8. Hasil Pengujian Database Sensor Asap MQ-7

\begin{tabular}{cccccc}
\hline No & Data & $\begin{array}{c}\text { Data Realtime } \\
\text { Database }\end{array}$ & $\begin{array}{c}\text { Data } \\
\text { Aplikasi }\end{array}$ & Sesuai & $\begin{array}{c}\text { Tidak } \\
\text { Sesuai }\end{array}$ \\
\hline 1 & Asap A1 & Ada & Ada & $\checkmark$ & \\
2 & Asap A2 & $\begin{array}{c}\text { Tidak } \\
\text { Ada }\end{array}$ & Tidak Ada & $\checkmark$ & \\
& & Tidak & Tidak Ada & $\checkmark$ & \\
3 & Asap B1 & Ada & Ada & $\checkmark$ & \\
4 & Asap B2 & Ada & Ada & \\
\hline
\end{tabular}

Berdasarkan data pada tabel diatas dapat diketahui bahwa semua data sensor asap yang ditampilkan di aplikasi sesuai dengan data yang disimpan di realtime database sehingga dapat disimpulkan bahwa realtime database sensor asap MQ-7 yang digunakan memiliki accuration rate sebesar $100 \%$.

- Tabel 9. Hasil Pengujian Database Sensor Suhu LM35

\begin{tabular}{cccccc}
\hline No. & Data & $\begin{array}{c}\text { Data Realtime } \\
\text { Database }\end{array}$ & $\begin{array}{c}\text { Data } \\
\text { Aplikasi }\end{array}$ & Sesuai & $\begin{array}{c}\text { Tidak } \\
\text { Sesuai }\end{array}$ \\
\hline 1 & Suhu A1 & $40^{\circ} \mathrm{C}$ & $40^{\circ} \mathrm{C}$ & $\checkmark$ & \\
2 & Suhu A2 & $34^{\circ} \mathrm{C}$ & $34^{\circ} \mathrm{C}$ & $\checkmark$ & \\
3 & Suhu B1 & $34^{\circ} \mathrm{C}$ & $34^{\circ} \mathrm{C}$ & $\checkmark$ & \\
4 & Suhu B2 & $39^{\circ} \mathrm{C}$ & $39^{\circ} \mathrm{C}$ & $\checkmark$ & \\
\hline
\end{tabular}

Berdasarkan data pada tabel diatas dapat diketahui bahwa semua data sensor suhu yang ditampilkan di aplikasi sesuai dengan data yang disimpan di realtime database sehingga dapat disimpulkan bahwa realtime database sensor suhu LM35 yang digunakan memiliki accuration rate sebesar $100 \%$.

\section{b. Pengujian Compatibility Aplikasi}

Pada hasil pengujian ini akan dilihat apakah aplikasi "Siaga Api" dapat berjalan pada berbagai environment yang berbeda. Hasil dari pengujian compatibility aplikasi ditunjukkan pada Tabel 10, dan Tabel 11.

- Tabel 10. Hasil Pengujian Instalasi Aplikasi "Siaga Api"

\begin{tabular}{|c|c|c|c|}
\hline \multirow{2}{*}{ No. } & \multirow{2}{*}{ Perangkat } & \multicolumn{2}{|c|}{ Proses Instalasi } \\
\cline { 3 - 4 } & & Berhasil & $\begin{array}{c}\text { Tidak } \\
\text { Berhasil }\end{array}$ \\
\hline 1 & $\begin{array}{c}\text { Samsung } \\
\text { Galaxy A32 }\end{array}$ & $\checkmark$ & \\
\hline 2 & Oppo A57 & $\checkmark$ & \\
\hline 3 & $\begin{array}{c}\text { Xiaomi Redmi } \\
\text { Note 10 }\end{array}$ & $\checkmark$ & \\
\hline 4 & $\begin{array}{c}\text { Samsung } \\
\text { Galaxy A20 }\end{array}$ & $\checkmark$ & \\
\hline 5 & Asus Zenfone 5 & $\checkmark$ & \\
\hline
\end{tabular}


Berdasarkan data pada tabel diatas dapat diketahui bahwa aplikasi "Siaga Api" dapat diinstal pada 5 perangkat handphone berbeda yang diuji cobakan. Hal ini menunjukan bahwa aplikasi ini kompatibel untuk diinstal di berbagai perangkat dengan environment berbeda. Pada pengujian ini maka skor yang didapat adalah 5 poin.

- Tabel 11. Perangkat Handphone yang Digunakan

\begin{tabular}{|c|c|c|c|c|c|c|}
\hline $\begin{array}{l}\text { No } \\
\cdot\end{array}$ & $\begin{array}{c}\text { Halaman } \\
\text { Aplikasi }\end{array}$ & $\begin{array}{c}\text { Samsung } \\
\text { Galaxy } \\
\text { A32 }\end{array}$ & $\begin{array}{c}\text { Oppo } \\
\text { A57 }\end{array}$ & $\begin{array}{l}\text { Perangkat } \\
\text { Xiaomi } \\
\text { Redmi } \\
\text { Note } 10\end{array}$ & $\begin{array}{c}\text { Samsung } \\
\text { Galaxy } \\
\text { A20 }\end{array}$ & $\begin{array}{c}\text { Asus } \\
\text { Zenfone } \\
5\end{array}$ \\
\hline 1 & Splash Screen & $\checkmark$ & $\checkmark$ & $\checkmark$ & $\checkmark$ & $\checkmark$ \\
\hline 2 & Login & $\checkmark$ & $\checkmark$ & $\checkmark$ & $\checkmark$ & $\checkmark$ \\
\hline 3 & Registrasi & $\checkmark$ & $\checkmark$ & $\checkmark$ & $\checkmark$ & $\checkmark$ \\
\hline 4 & $\begin{array}{c}\text { Lupa } \\
\text { Password }\end{array}$ & $\checkmark$ & $\checkmark$ & $\checkmark$ & $\checkmark$ & $\checkmark$ \\
\hline 5 & Verifikasi & $\checkmark$ & $\checkmark$ & $\checkmark$ & $\checkmark$ & $\checkmark$ \\
\hline 6 & Status & $\checkmark$ & $\checkmark$ & $\checkmark$ & $\checkmark$ & $\checkmark$ \\
\hline 7 & Api & $\checkmark$ & $\checkmark$ & $\checkmark$ & $\checkmark$ & $\checkmark$ \\
\hline 8 & Asap & $\checkmark$ & $\checkmark$ & $\checkmark$ & $\checkmark$ & $\checkmark$ \\
\hline 9 & Suhu & $\checkmark$ & $\checkmark$ & $\checkmark$ & $\checkmark$ & $\checkmark$ \\
\hline 10 & Tentang & $\checkmark$ & $\checkmark$ & $\checkmark$ & $\checkmark$ & $\checkmark$ \\
\hline 11 & $\begin{array}{l}\text { Tentang } \\
\text { Aplikasi }\end{array}$ & $\checkmark$ & $\checkmark$ & $\checkmark$ & $\checkmark$ & $\checkmark$ \\
\hline 12 & Tentang Kami & $\checkmark$ & $\checkmark$ & $\checkmark$ & $\checkmark$ & $\checkmark$ \\
\hline
\end{tabular}

Berdasarkan data pada tabel diatas dapat diketahui bahwa semua perangkat yang diuji cobakan berhasil menjalankan aplikasi dengan lancar dan dapat membuka semua halaman aplikasi. Hal ini menunjukan bahwa aplikasi ini kompatibel untuk dijalankan di berbagai perangkat dengan environment berbeda. Pada pengujian ini maka skor yang didapat adalah 60 poin.

Berdasarkan data hasil pengujian pada Tabel 10 dan Tabel 11 diatas, maka selanjutnya perlu menghitung persentase kelayakan aplikasi dengan menggunakan perhitungan sebagai berikut.

$$
\begin{aligned}
\text { Persentase keberhasilan }(\%) \quad & \frac{5+60}{65} \times 100 \% \\
& =100 \%
\end{aligned}
$$

Berdasarkan perhitungan tersebut maka hasil persentase kelayakan yang didapatkan hasilnya adalah 100\% maka aplikasi "Siaga Api" memenuhi standar aspek compatibility dengan kategori "sangat layak".

\section{c. Pengujian Usability Aplikasi}

Pada pengujian ini didapatkan hasil responden sebanyak 15 responden. Dari hasil jawaban responden terhadap kuesioner kemudian akan dirangkum dan akan dihitung skor untuk masing-masing pertanyaan. Hasil dari pengujian usability aplikasi ditunjukkan pada Tabel 12, dan Tabel 13. 
- Tabel 12. Rangkuman Hasil Jawaban Responden Terhadap Kuesioner

\begin{tabular}{ccccccccccc}
\hline \multirow{2}{*}{ Responden } & \multicolumn{10}{c}{ Skor Asli } \\
\cline { 2 - 10 } & Q1 & Q2 & Q3 & Q4 & Q5 & Q6 & Q7 & Q8 & Q9 & Q10 \\
\hline 1 & 4 & 2 & 5 & 2 & 4 & 2 & 5 & 1 & 5 & 1 \\
2 & 4 & 1 & 4 & 1 & 4 & 1 & 5 & 1 & 5 & 1 \\
3 & 5 & 1 & 5 & 1 & 5 & 1 & 5 & 1 & 5 & 1 \\
4 & 5 & 2 & 5 & 3 & 5 & 2 & 5 & 3 & 5 & 2 \\
5 & 4 & 1 & 3 & 1 & 4 & 4 & 5 & 1 & 2 & 1 \\
6 & 4 & 3 & 4 & 2 & 4 & 3 & 4 & 3 & 3 & 2 \\
7 & 5 & 1 & 4 & 1 & 5 & 1 & 5 & 1 & 5 & 1 \\
8 & 4 & 1 & 5 & 1 & 5 & 1 & 5 & 1 & 5 & 2 \\
9 & 5 & 1 & 5 & 1 & 5 & 1 & 5 & 1 & 5 & 1 \\
10 & 5 & 1 & 5 & 1 & 5 & 1 & 5 & 1 & 5 & 1 \\
11 & 5 & 2 & 5 & 2 & 5 & 2 & 5 & 2 & 5 & 2 \\
12 & 5 & 2 & 5 & 2 & 5 & 2 & 5 & 2 & 5 & 2 \\
13 & 4 & 3 & 4 & 4 & 5 & 1 & 3 & 4 & 3 & 1 \\
\hline
\end{tabular}

Tabel 13. Perhitungan Persentase Hasil Kuesioner

\begin{tabular}{|c|c|c|c|c|c|c|c|c|c|c|c|c|}
\hline \multirow{2}{*}{ Responden } & \multicolumn{10}{|c|}{ Skor Hasil Hitung } & \multirow{2}{*}{ Jumlah } & \multirow{2}{*}{$\begin{array}{c}\text { Skor } \\
(\%)\end{array}$} \\
\hline & Q1 & $\mathbf{Q 2}$ & $\mathbf{Q 3}$ & $\overline{Q 4}$ & $\overline{\text { Q5 }}$ & Q6 & Q7 & Q8 & Q9 & Q10 & & \\
\hline 1 & 3 & 3 & 4 & 3 & 3 & 3 & 4 & 4 & 4 & 4 & 35 & 88 \\
\hline 2 & 3 & 4 & 3 & 4 & 3 & 4 & 4 & 4 & 4 & 4 & 37 & 93 \\
\hline 3 & 4 & 4 & 4 & 4 & 4 & 4 & 4 & 4 & 4 & 4 & 40 & 100 \\
\hline 4 & 4 & 3 & 4 & 2 & 4 & 3 & 4 & 2 & 4 & 3 & 33 & 83 \\
\hline 5 & 3 & 4 & 2 & 4 & 3 & 1 & 4 & 4 & 1 & 4 & 30 & 75 \\
\hline 6 & 3 & 2 & 3 & 3 & 3 & 2 & 3 & 2 & 2 & 3 & 26 & 65 \\
\hline 7 & 4 & 4 & 3 & 4 & 4 & 4 & 4 & 4 & 4 & 4 & 39 & 98 \\
\hline 8 & 3 & 4 & 4 & 4 & 4 & 4 & 4 & 4 & 4 & 3 & 38 & 95 \\
\hline 9 & 4 & 4 & 4 & 4 & 4 & 4 & 4 & 4 & 4 & 4 & 40 & 100 \\
\hline 10 & 4 & 4 & 4 & 4 & 4 & 4 & 4 & 4 & 4 & 4 & 40 & 100 \\
\hline 11 & 4 & 3 & 4 & 3 & 4 & 3 & 4 & 3 & 4 & 3 & 35 & 88 \\
\hline 12 & 4 & 3 & 4 & 3 & 4 & 3 & 4 & 3 & 4 & 3 & 35 & 88 \\
\hline 13 & 3 & 2 & 3 & 1 & 4 & 4 & 2 & 1 & 2 & 4 & 26 & 65 \\
\hline 14 & 3 & 3 & 3 & 3 & 4 & 3 & 4 & 3 & 4 & 3 & 33 & 83 \\
\hline 15 & 3 & 3 & 3 & 3 & 3 & 3 & 3 & 3 & 4 & 3 & 31 & 78 \\
\hline \multicolumn{12}{|c|}{ Skor Rata-Rata (\%) } & 86 \\
\hline
\end{tabular}

Berdasarkan data pada tabel diatas maka didapatkan bahwa skor tertinggi adalah 100 berdasarkan jawaban dari responden 3, 9, dan 10. Sedangkan skor terendah adalah 65 berdasarkan jawaban dari responden 6 dan 13. Dan rata-rata persentase skor keseluruhan adalah 86. Rata-rata persentase yang telah didapatkan selanjutnya dikonversikan sesuai standar ISO/EIC 25010. Dengan nilai standar kelayakan sebesar 86\% maka aplikasi "Siaga Api" memenuhi standar aspek usability dengan kategori "sangat layak".

\section{d. Pengujian Performance Efficiency Aplikasi}

Pada pengujian ini didapatkan persentase pemakaian CPU usage serta memory device pada saat menjalankan aplikasi "Siaga Api". Pengujian ini dilakukan selama 1 menit 4 detik melalui simulation device Pixel 3, API Level 28. Grafik hasil performansi CPU usage dan memory saat menjalankan aplikasi "Siaga Api' ditunjukkan pada Gambar 8. 


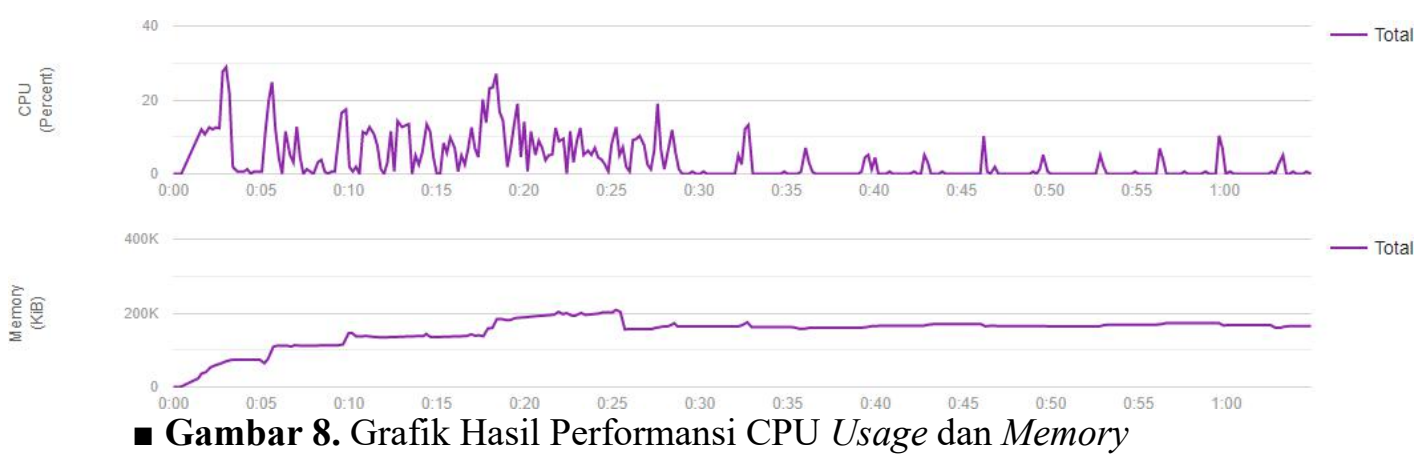

Hasil dari pengujian performance efficiency aplikasi ditunjukkan pada Tabel 14, dan Tabel 15.

- Tabel 14. Hasil Pengujian CPU Usage

\begin{tabular}{ccc}
\hline No. & $\begin{array}{c}\text { Menit } \\
\text { Ke- }\end{array}$ & $\begin{array}{c}\text { Penggunaan } \\
\text { CPU (\%) }\end{array}$ \\
\hline 1 & 0.05 & 0,625 \\
2 & 0.1 & 1,911 \\
3 & 0.15 & 5,66 \\
4 & 0.2 & 14,103 \\
5 & 0.25 & 8,075 \\
6 & 0.3 & 0,637 \\
7 & 0.35 & 0,621 \\
8 & 0.4 & 4,403 \\
9 & 0.45 & 0,625 \\
10 & 0.5 & 0,629 \\
11 & 0.55 & 0,633 \\
12 & 1 & 0,629 \\
\hline \multicolumn{3}{l}{ Rata-Rata } \\
\hline
\end{tabular}

Berdasarkan data pada tabel diatas rata-rata performance CPU usage dari aplikasi "Siaga Api" adalah sebesar 3,213\%. Nilai rata-rata tersebut masih berada dibawah batas aman yang ditetapkan oleh standar little eye tools untuk CPU usage, yaitu sebesar 15\%.

- Tabel 15. Hasil Penggunaan Memory

\begin{tabular}{ccc} 
No. & $\begin{array}{c}\text { Menit } \\
\text { Ke- }\end{array}$ & $\begin{array}{c}\text { Penggunaan } \\
\text { Memory }(\text { KB) }\end{array}$ \\
\hline 1 & 0.05 & 74,912 \\
2 & 0.1 & $1,45,816$ \\
3 & 0.15 & $1,36,608$ \\
4 & 0.2 & $1,89,448$ \\
5 & 0.25 & $2,02,060$ \\
6 & 0.3 & $1,63,760$ \\
7 & 0.35 & $1,61,928$ \\
8 & 0.4 & $1,65,632$ \\
9 & 0.45 & $1,70,056$ \\
10 & 0.5 & $1,64,360$
\end{tabular}




\begin{tabular}{|ccc|}
\hline 11 & 0.55 & $1,68,536$ \\
12 & 1 & $1,67,436$ \\
\hline \multicolumn{2}{|c|}{ Rata-Rata } & $1,59,213$ \\
\hline
\end{tabular}

Berdasarkan data pada tabel diatas dapat diketahui bahwa rata-rata penggunaan memory pada aplikasi "Siaga Api" yaitu sebesar 159,213 KB. Nilai tersebut dapat dikatakan cukup kecil untuk penggunaan memory sebuah aplikasi. Dalam pengujianya pun aplikasi tidak mengalami memory leaks, yaitu suatu keadaan dimana resource dari aplikasi yang dialokasikan pada memory tidak mampu dibebaskan sehingga dapat menyebabkan sistem crash.

\section{e. Pengujian Sistem Notifikasi Peringatan}

Pengiriman notifikasi peringatan dilakukan secara otomatis oleh cloud function firebase, terdapat 2 fungsi yang di deploy untuk menjalankan perintah otomatis pengiriman notifikasi peringatan kepada pengguna. Kedua fungsi tersebut tertera pada Tabel 16 dibawah ini.

- Tabel 16. Cloud Function Sistem Notifikasi Peringatan

\begin{tabular}{ccl} 
No. & Nama Fungsi & \multicolumn{1}{c}{ Kegunaan } \\
\hline 1 & sendNotif & $\begin{array}{l}\text { Mengirimkan push notification kepada pengguna } \\
\text { jika terjadi perubahan status di Node A } \\
\text { Mengirimkan push notification kepada pengguna } \\
\text { jika terjadi perubahan status di Node B }\end{array}$ \\
\hline
\end{tabular}

Kedua fungsi tersebut akan menjalankan tugasnya ketika ada trigger yaitu perubahan data status pada realtime database. Pada pengujian ini kedua fungsi tersebut diukur waktu eksekusi fungsinya dengan menggunakan function logs ketika ada fungsi yang dieksekusi. Berdasarkan nilai yang terukur pada function logs Firebase maka didapatkan nilai waktu pengeksekusian setiap fungsi pada saat pengujian berlangsung. Nilai tersebut ditunjukkan pada Tabel 17 dibawah ini.

- Tabel 17. Waktu Eksekusi Fungsi Pada Cloud Function Firebase

\begin{tabular}{ccccccc}
\hline No. & Fungsi & Aman & Waspada & $\begin{array}{c}\text { Waktu Eksekusi } \\
\text { Ktatus } \\
\text { Leval 1 }\end{array}$ & $\begin{array}{c}\text { Kebakaran } \\
\text { Level 2 }\end{array}$ & $\begin{array}{c}\text { Rata-Rata } \\
\text { Eksekusi }\end{array}$ \\
\hline 1 & sendNotif & $415 \mathrm{~ms}$ & $456 \mathrm{~ms}$ & $320 \mathrm{~ms}$ & $329 \mathrm{~ms}$ & $380 \mathrm{~ms}$ \\
2 & sendNotifB & $348 \mathrm{~ms}$ & $332 \mathrm{~ms}$ & $320 \mathrm{~ms}$ & $365 \mathrm{~ms}$ & $341 \mathrm{~ms}$ \\
\hline
\end{tabular}

Waktu eksekusi yang tertera pada tabel diatas merupakan waktu Firebase untuk memproses atau menjalankan perintah yang tertera dalam cloud function. Fungsi pengiriman push notification untuk Node A (sendNotif) memiliki rata-rata waktu eksekusi sebesar $380 \mathrm{~ms}$, dan fungsi pengiriman push notification untuk Node B (sendNotifB) memiliki rata-rata waktu eksekusi sebesar $341 \mathrm{~ms}$. Ratarata waktu eksekusi berada pada kisaran $100 \mathrm{~ms}-400 \mathrm{~ms}$, sehingga dapat dikategorikan acceptable berdasarkan standar QRTi MySQL Enterprise yang artinya nilai tersebut dapat diterima.

\section{KESIMPULAN}

1. Mobile application pada sistem pendeteksi dini kebakaran lahan berbasis Android merupakan sebuah aplikasi yang didesain untuk pada pengguna Android dan berfungsi untuk melakukan pemantauan lahan yang menampilkan data-data ada atau tidak adanya api dari sensor api flame detectors, ada atau tidak adanya asap dari 
2. sensor asap MQ-7, dan besaran nilai suhu dari sensor suhu LM35, yang jika ada perubahan status maka user akan menerima push notification berupa perubahan status "aman", "waspada", "kebakaran level 1", atau "kebakaran level 2".

3. Kualitas aplikasi "Siaga Api" dinilai berdasarkan aspek compatibility, usability, dan performance efficiency. Pada aspek compatibility aplikasi memiliki persentase skor kelayakan sebesar $100 \%$, sehingga berdasarkan standar ISO/EIC 25010 termasuk kedalam kategori sangat layak. Dari aspek usability memiliki persentase skor kelayakan sebesar $86 \%$ sehingga juga termasuk kedalam kategori sangat layak, dan dari performance efficiency rata-rata persentase CPU usage sebesar $3,213 \%$ nilai ini masih berada dalam batas aman standar yg ditetapkan little eye tools yaitu $15 \%$ dan penggunaan memory saat menjalankan aplikasi pun terbilang cukup kecil yaitu hanya sebesar $159,213 \mathrm{~KB}$.

4. Performansi layanan database yang digunakan pada sistem ini memiliki kemampuan yang cukup baik dalam pengiriman push notification. Pada Node A rata-rata waktu eksekusinya adalah $380 \mathrm{~ms}$, dan pada Node B rata-rata waktu eksekusinya adalah $341 \mathrm{~ms}$. Rata-rata waktu eksekusi tersebut berada pada range $100 \mathrm{~ms}$ - 400ms sehingga dapat dikatakan acceptable berdasarkan standar QRTi MySQL Enterprise karena pada sistem ini data yang tersimpan secara realtime dapat langsung diketahui oleh client.

\section{DAFTAR PUSTAKA}

[1] SiPongi. "Rekapitulasi Luas Kebakaran Hutan dan Lahan (Ha) Per Provinsi Di Indonesia Tahun 2016- 2021”. Internet : http://sipongi.menlhk.go.id/hotspot/luas_kebakaran. [4 Juli 2021]

[2] PRIMS. "Perencanaan Restorasi di 7Provinsi Prioritas", 2020. Internet: https://prims.brg.go.id/dasbor/restorasi. [4 Juli2021]

[3] BNPB (Badan Nasional Penanggulangan Bencana). "Definisi Bencana". Internet: https://bnpb.go.id/definisi-bencana. [4 Juli 2021]

[4] Sasmoko, D. \& Mahendra, A.: Rancang Bangun Sistem Pendeteksi Kebakaran Berbasis IoT dan SMS Gateway Menggunakan Arduino. Indonesia: Semarang. 2017.

[5] Siswanto, dkk.: Prototype Wireless Sensor Network (WSN) Sistem Pendeteksi Dini Kebakaran Hutan. Indonesia: Serang. 2020.

[6] Joniwarta, dkk.: Sistem Monitoring Kebakaran Berbasis SMS Gateway. Indonesia: Jakarta. 2019. 